\title{
Development of the export potential of Russian education in the modern strategic discourse
}

\author{
Olga Fedotova $^{1 *}$,Elena Platonova $^{2}$,Elena Tregubenko², and Grant Avanesyan ${ }^{3}$ \\ ${ }^{1}$ Don State Technical University, Faculty "Psychology, Pedagogy and Defectology", \\ 344000, Rostov on Don, Russian Federation \\ ${ }^{2}$ Moscow Pedagogical State University, Institute of Social Studies and Humanities, 119571, \\ Moscow, Russian Federation \\ ${ }^{3}$ Yerevan State University, Faculty of Philosophy and Psychology, 0025, Yerevan, \\ Republic of Armenia
}

\begin{abstract}
The article considers approaches to the strategies of educational export development in the Russian Federation in terms of its value for implementation of national economic, cultural and international policies. Two projects have been identified as having the status of official documents regulating the activities of government agencies. These documents are analyzed through the prism of their objectives, dynamics of the estimated foreign students' flow, funding, implementation steps. The conclusion is made on inconsistency of educational export strategic planning, as well as on the activities of its elimination.
\end{abstract}

\section{Introduction}

Having entered the global market of science and education, Russia has opened up new prospects for the development of all areas of socio-economic practices. The modern system of Russian education is a significant sociocultural phenomenon and a mechanism for preserving and enhancing cultural traditions, as well as regularly training specialists able to increase the economic and intellectual power of the country. At the same time, it is an important source of non-resource export, which is included in the global business system and generates significant income. Education export is not only a commercial, but also a geopolitical task, since, acting as a "soft power" [1], it allows foreign participants to know the national priorities and values and cultivates respect.

The problems associated with the spread of educational practices outside the exporting country have always been a topic of scientific discussion. Despite the complexity of the processes associated with the export of Russian education, the intensity and level of discussion on the pages of the world pedagogical press are insufficient. The foreign reader does not receive information about the whole variety of approaches to Russian education export, as well as the intrinsic difficulties and risks. The debates commonly cover various aspects of improving the quality of educational activities in various organizations in order to

\footnotetext{
*Corresponding author: fod1953@yandex.ru
} 
attract students within the context of human capital development and economic effeciency $[2,3,4,5,6]$, education for migrants in the context of the internationalization of education $[7,8,9]$. Among the authors who have addressed this issue there are very few non-Russian (foreign) specialists - with the exception of an employee P.W. Thurman, affiliated with Columbia University in the City of New York, New York, United States [10].

An analysis of the thesis papers by Russian authors showed that in the framework of sociological research, the problem of exporting education is considered in the logic of structuring the demand of applicants from the CIS countries and constructing the role of the state in its promotion [11]. Rogovaya T.M. has evaluated the factors that determine the choice of educational services in higher education and also the author has developed a system of measures to increase the influx of foreign students [12]. World experience and the Russian practice of exporting educational services are compared in the dissertation of A.V. Kosevich [13]. The chronological framework of the above studies is limited to the period $2006-2017$ and does not take into account new circumstances associated with the emergence of modern export strategies for Russian education. The studies were carried out in an applied manner and characterize specific measures for the education export, without affecting the strategic aspects of its development. The above issues are relevant to the analysis of modern strategies of the Russian Federation in the field of export of educational services.

The purpose of the article is to analyze new strategic objectives in the field of export of education and approaches to their practical implementation adopted in the Russian Federation in recent years. The problem of the study is to establish the fact that two concepts for developing Russian education export potential have official status at the Federal level and these concepts were adopted by various departments. In this regard, it is necessary to clarify what are the similarities and differences in their provisions.

\section{The concept and methodology of the study}

The empirical array is the passport texts of two official concepts of Russian education export development. Chronologically, the first was the concept "Development of the export potential of the Russian education system" (hereinafter referred to as Project 2017), approved by the Presidium of the Presidential Council for Strategic Development and Priority Projects $\begin{array}{llll}\text { (Minutes No. } & 6 & \text { 05/30/2017) }\end{array}$ [http://www.consultant.ru/cons/cgi/online.cgi?req=doc\&base=LAW\&n]. In 2018, the passport of the Federal project "Export of Education" was approved (Project Committee for the national project "Education", protocol No. 3 dated December 7, 2018), next - Project 2018 [http://www.stavregion.ru/programms/proektnyj-ofis].

Research methods - cluster analysis, content analysis, comparative analysis, generalization, interpretation.

\section{Results and discussion}

At the first stage, the aim was to determine the purpose of the concepts and their structural features that shape the content and system of implementation measures. The project passport as an official document has a fairly clear structure, which defines the purpose of the project, its contents, expected results, means of achieving and / or financial support for the project and the risks associated with its implementation. These positions allow a correct comparative analysis and determine their qualitative identity.

The most important position determining the essence of the project is the goal of the project. According to the wording presented in the document "Export Potential Development", it is an increase in the share of non-oil exports of the Russian Federation by 
increasing the attractiveness of Russian education in the international educational market. The project "Export of Education" (Project 2018) sets up a specific goal to increase "the number of foreign citizens studying full-time in organizations engaged in educational activities under higher education programs". The number of the students should be increased from 241 thousand people in 2019 to 425 thousand people in 2024. As follows from the definitions given above, in the first case we are dealing with the strategic vector of the development of education export of education, while in the second one - with the indicator of the desired dynamics.

The second stage of the study was to determine the planned indicators as a result of the implementation of both projects. Summary data is presented in Fig. 1.

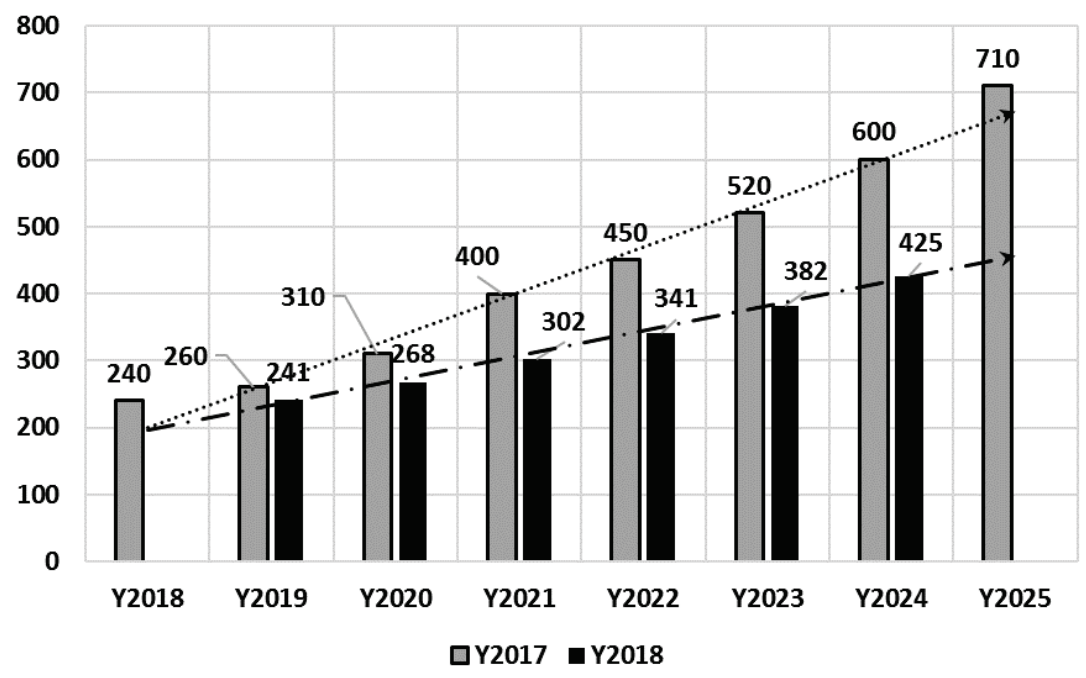

Fig. 1. Comparison of the number of foreign students in Project 2018 and Project 2017 for the aim of the development of export of Russian education (unit of measurement is one thousand)

As seen in the overall data, within the upward trend the dynamics of the planned growth in the number of the foreign students significantly differs. As the projects are being implemented, discrepancies continue to increase. In addition, the projects cover different implementation time periods, which indicates a lack of consistency between these strategic documents.

The common position in both analyzed projects is funding. Figure 2 shows the comparison of the estimated financial support of the Project 2017 and Project 2018. 


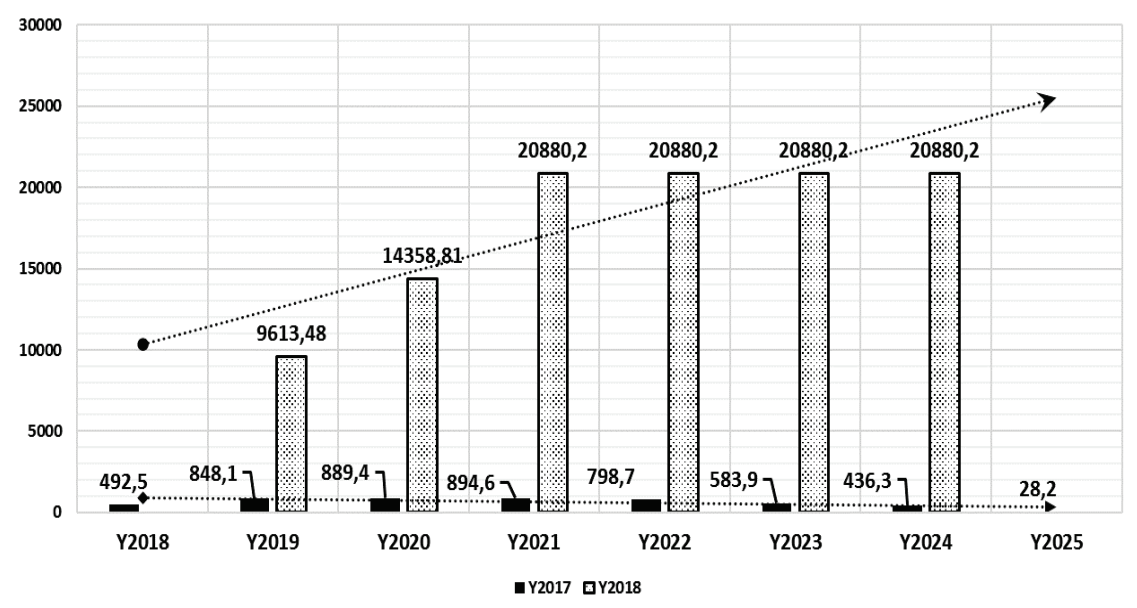

Fig. 2. Comparison of the estimated financial support of the Russian education export projects (the unit of measure is million rubles).

The bar chart clearly shows that the funds planned (or already allocated) for the implementation of the projects are not comparable in volume. Within the framework of the planned projects, various time periods for their implementation are provided. For the project "Development of the export potential of the Russian education system," financing cover the period of 2018-2025. Moreover, the funding is planned to be increased in the first four years followed by a decrease. This is quite explained by the fact that project will be solved some of the issues including the optimization of the costs of outreach and recommendations for Russian educational organizations to promote Russian educational programs based on marketing research on the international educational market. In comparison with the expenses planned in that project, large-scale financing the Federal project "Education Export" (Project 2018 ) is envisaged. The budget of Project 2018 will be increased significantly in 2021 and funding will continue in significant volume until the end of the project. In this regard, the question arises of those activities that are planned within the projects.

The third stage of the study presents an analysis of the general character and the specificities, shaping the measures provided by these projects. The comparison of the planned results of two projects allowed us to identify three clusters of activities and results that are common to both projects. The first cluster is the design, construction, reconstruction and functioning of campuses for foreign students. The second cluster is improvement of the rules for foreign students' entry and stay in the Russian Federation for the purpose of education and further employment. The third cluster is ensuring international recognition of Russian educational programs and qualifications, including through their international accreditation and certification. The both projects include a system of the activities to attract of the schoolchildren to the additional education, including summer training in the recreation camps and the distance learning courses. However, there are differences characteristic of both the structure of the projects and their content.

In terms of content, it is interesting to have a system of the activities that ensures the practical inclusion of Russian and foreign citizens in the popularization of domestic education export programs. The project "Development of the export potential of the Russian education system" includes the original program of "Ambassadors of Russian Education", which one triggers the initiatives to popularize the system of Russian education between all typological groups (for instance, the Russian-speaking graduates of Russian universities living abroad; students participating in academic mobility programs; teachers working abroad by contract, 
etc.). Congresses and exhibition events, the implementation of the "Educational Tourist Routes of Russia" program, the development and implementation of the standard "Training for Foreign Citizens and Stateless Persons in the Russian Federation" are pursuing the same goal in Project 2017.

The project "Export of Education" focuses on the setting up of the resource centers for children and teachers, ensuring the popularization of the study at an advanced level of such general subjects as mathematics, biology, chemistry, physics, astronomy and others. That project provides for the development of specialized Internet sites to attract foreign nationals targeting specific audiences, taking into account the reference groups of partner countries. In addition, these projects include the activities for the employment of foreign students who completed their studies in organizations engaged in educational activities in higher education programs in Russian companies including those with branches abroad. Thus, both projects are characterized by duplication of educational export strategies in certain positions. At the same time in these projects there are some differences in the system of the activities to implement these strategies.

\section{Conclusion}

The fact of the simultaneous coexistence of two documents that are strategically important for the development of the export system of Russian education indicates that, firstly, this area of socio-economic practice is not yet fully mastered by Russian universities. Secondly, the education export strategy should include a wider range of activities, including those accepted in the world practice for the implementation of educational services (opening branches of educational organizations abroad, the development of academic mobility and educational migration, support for open educational platforms, training practices in double degree programs, etc.). Thirdly, there is a weak coordination in the work of various government departments and management structures responsible for the setting up and implementation of strategy of the export of Russian education, as well as the presence of unresolved issues related, inter alia, to recognition of periods of study and qualification. The solution of these issues will accelerate the processes of implementation of strategic tasks to increase of the export potential of Russian education as a strategic direction of the modern policy of the Russian Federation.

This article was prepared with the support of the Grant of Russian Foundation for Basic Research 1829-22004 "Psychological and genetic research of predictors that determine the behavior of users in the perception of Internet - content of various informational directions".

Authors thank the Russian Foundation for Basic Research for their support.

\section{References}

1. E.A. Antyukhova, Vestnik TGU, 57, 41-45 (2019)

2. Y.N. Zelenov, A.V. Gubareva, K.E. Kovalenko, Revista universidad y Sociedad. 9(5), 282-284 (2017)

3. A.Y. Aleksandrov, S.V. Barabanova, S.B. Vereshchak, Modern journal of language teaching methods, 7(5) 29-39 (2017)

4. V. Perepelkin, E. Perepelkina, Comparative economic research-central and eastern Europe. 20(1) 53-73 (2017)

5. O. Fedotova, E. Platonova, Procedia Social and Behavioral Sciences. 141, 1177-1191 (2014)

6. O.A. Shvetsova. International Multidisciplinary Scientific GeoConference-SGEM, 1047-1054 (2016) 
7. S. Dryga, E. Giniyatova, D. Poletaev. European Proceedings of Social and Behavioural Sciences. 19, 159-164 (2017)

8. O. Fedotova, EDULEARN Proceedings, 45-54 (2012)

9. O.M. Lenkovets, N.Y. Kirsanova, International Multidisciplinary Scientific Conferences on Social Sciences and Arts. 559-564 (2016)

10. P.W. Thurman, I. Efimova. Life Science Journal. 11(11), 285-289 (2014)

11. A. Nefedova, Export of Russian higher education: features of the formation and structuring of demand: dissertation (Moscow, 2017)

12. T. Rogova, Export of educational services of Russian universities: barriers and prospects (Rostov on Don, 2013)

13. A. Kosevich, Export of educational services in the field of higher education: world experience and Russian practice (Moscow, 2006) 